\title{
EDITORIAL NOTE \\ Vegetation replacement in Rio de Janeiro during the last 7,000 years B.C., genetic variation in the medicinal plant Lippia alba (Verbenaceae), and short review of Chagas disease in prehistory
}

\author{
ALEXANDER W.A. KELLNER \\ Editor-in-chief
}

According to historians, when the northern coast of Rio de Janeiro State was reached by European colonizers, they encountered vast herbaceous fields instead of a rich and diversified forest. This has led to an interesting question: how were these fields formed?

The present issue of the Anais da Academia Brasileira de Ciências (AABC) presents an important contribution that sheds new light on this problem. Luz et al. (2011) have studied two core samples from the municipality of Campos dos Goytacazes, located in the northern costal region of Rio de Janeiro. Their aim was to understand the changes of the vegetation during the last 7,000 years B.C. based on palynological evidences. Palynomorphs have already been found in this region (e.g., Luz et al. 2010), but were not studied in detail throughout the cores.

Luz et al. (2011) have shown that there were changes in successions of vegetational patterns, some due to flooding events during the Holocene and others as a response to sea level changes. However, no evidence of the use of fire or other agricultural activities by the Goitacás Indians was showed in the cores studied by these authors. This contradicts theories that have at least partially attributed the actions of these indigenous groups to the origin of these fields.

Another interesting study published in this volume of the AABC is on the genetic variation in Lippia alba (Verbenaceae). This medicinal plant is used in gastrointestinal and respiratory disorders, among others. As has been observed before, Lippia alba shows variations in both morphology and composition of its oil, leading to the establishment of several chemotypes (e.g., Hennebelle et al. 2008) that varied even under identical environmental conditions. This led to the suspicion that a genetic control might be responsible for these differences.

To further investigate this issue, Pierre et al. (2011) employed various techniques to assess the genetic variability in three chemotypes of Lippia alba. This included random amplified polymorphic DNA (RAPD) marker, which is commonly used for genetic characterization (e.g., Londe et al. 2010). Pierre et al. (2011) concluded that the differences of the chemotypes of Lippia alba might be the result of the beginning of reproductive isolation. This type of study is quite interesting, since it might help us to better understand how new species might originate.

Lastly, Ferreira et al. (2011) provide a short review regarding the Chagas disease in prehistory. As they pointed out, the origin of Trypanosoma cruzi - the parasite responsible for Chagas disease in humans - is still disputed, with the classical hypothesis advocating that this disease has originated in the Andean region, when the local population started to domesticate several animals. The extraction of Trypanosoma cruzi DNA from mummified bodies (e.g., Madden et al. 2001) apparently confirmed this hypothesis. However, as Ferreira et al. (2011) discuss, there have been recently several other lines of evidences, mainly paleoparasitological data, suggesting that Chagas disease is as old as the human presence in the Americas. 


\section{REFERENCES}

Ferreira LF, Jansen AM And Araújo A. 2011. Chagas disease in prehistory. An Acad Bras Cienc 83: 1041-1044.

Hennebelle T, Sahpaz S, Gressier B, Joseph H and Bailleul F. 2008. Antioxidant and neurosedative properties of polyphenols and iridoids from Lippia alba. Phytother Res 22: 256-258.

Londe LN, UeIRA-Vieira C, KerR WE And BonetTi AM. 2010. Characterization of DNA polymorphisms in Caryocar brasiliense (Camb.) in populations with and without thorn at the endocarp by RAPD markers. An Acad Bras Cienc 82: 779-789.

Luz CFP, Barth OM, Martin L, Silva CG and Turce BJ. 2011. Palynological evidence of the replacement of the hygrophilous forest by field vegetation during the last 7,000 years B.P. in the northern coast of Rio de Janeiro, Brazil. An Acad Bras Cienc 83: 939-951.

LUZ CFP, BARTH OM AND SILVA CG. 2010. Modern processes of palynomorph deposition at lakes of the northern region of the Rio de Janeiro State, Brazil. An Acad Bras Cienc 82: 679-690.

MADDEN M ET AL. 2001. Hybridization screening of very short PCR products for paleoepidemiological studies of Chagas' disease. Biotechniques 30: 102-104.

Pierre PMO, Sousa SM, Davide LC, Machado MA And Viccini LF. 2011. Karotype analysis, DNA content and molecular screening in Lippia alba (Verbenaceae). An Acad Bras Cienc 83: 993-1005. 